\title{
Seabed pockmarks in the southern Bulgarian Black Sea zone
}

\author{
L. DIMITROV \& V. DONTCHEVA
}

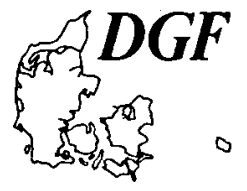
Dimitrov, L. \& Dontcheva, V.: Seabed pockmarks in the southem Bulgarian Black Sea zone.
Bulletin of the Geological Society of Denmark, vol. 41, pp. 24-33, Copenhagen, 1994-03-30.
https://doi.org/10.37570/bgsd-1995-41-02

\begin{abstract}
Pockmarks were discovered for the first time in the SE of the Bulgarian Black Sea zone in 1988. Echo sounder and shallow seismic data analyses of investigations conducted before and after 1988, allow the main pockmark area to be enlarged and given more details. A total of 305 pockmarks have been located within an area of more than $100 \mathrm{~km}^{2}(2-5 \mathrm{~km}$ wide and $41 \mathrm{~km}$ long). The bottom of the area is covered with Holocene soft silty clay. The following trends are defined when moving from the northern part of the pockmark area to the southem part: 1) increase in seabed sediments thickness from $2.5 \mathrm{~m}$ to more than $3.2 \mathrm{~m}$ and decrease in mean sediment grain size; 2) increase in general water depth from 160-300 m to 230-340 $\mathrm{m}$ in areas where pockmarks occur; 3 ) increase in average individual pockmark size from 86 to $132 \mathrm{~m}$ in diameter and from 2 to $4 \mathrm{~m}$ in depth; 4 ) decrease of pockmark density from $8-9$ p.m. $/ \mathrm{km}^{2}$ to $3-4$

p.m. $/ \mathrm{km}^{2}$ Similar trends are observed seaward where the pockmark profile shape changes from a smooth U-shaped to a sharp V-shaped form, with pockmark wall slope angle reaching more than $10^{\circ}$. A variety of acoustic anomalies such as acoustic turbidity, bright spots, enhanced reflections etc., are recorded in many places within the pockmark area, indicating the presence of gas in the sediments. Water column anomalies have also been recorded. The paper discusses the origin of the gas (most likely to be a mixture of thermogenic and biogenic gas) and the time of pockmark formation.
\end{abstract}

Lyobomir I. Dimitrov, Laboratory of Marine Geophysics. Valentina G. Dontcheva, Department of Marine Geology Institute of Oceanology, P.O. Box 152, 9000 Varna, Bulgaria. August 23rd, 1992.

\section{Introduction}

Since 1970, when King and MacLean (1970) recognized and described pockmarks for the first time as coneshaped depressions on the sea bed, such forms have been discovered in numerous basin areas: North Sea (Caston 1974; Jansen 1976; Hovland 1984), Norwegian Trench (Hovland 1981; 1983), Gulf of Mexico (Berard et al. 1976), Baltic Sea (Wemer 1978; Blazchishin \& Lange 1984), Bering Sea (Nelson et al. 1979) etc. Most of the authors support the hypothesis that pockmarks are formed as a result of gas escaping through the sediments to the sea water, either by seepage (Josenhans et al. 1978) or eruption (Hovland 1987). The fullest report about the areal extent of pockmarks in the World Ocean, their morphology, geological environments in which they are developed, the mechanism of their formation and some engineering and ecological aspects are contained in the generalized study written by Hovland and Judd (1988).

The mechanism of pockmark formation and their relation to gas-charged sediments may represent potential hazards to drilling, pipelines and other water and sea floor installations within the pockmark areas. This raises the necessity of investigating such areas to determine the pockmark distribution, the time of their formation, the post-formation activity and the possibility of their reactivation. In 1988 seabed forms similar to pockmarks were discovered in the upper part of the southem Bulgarian Black Sea continental slope (Dimitrov 1990). In addition, cone-shaped depressions were localized in the northern peripheral part of the shelf. Only shallow seismic and echo sounder systems were used for recognition of these forms, but their morphology allows one to identify them as pockmarks.

The purpose of this work is to study the areal extent of the pockmarks in the southem zone, their sizes, shapes, geological environment and related sub-surface and water column features. The echo sounder, shallow seismic and geological data analysis of the previous and present investigations allows the primary pockmark area to be enlarged and given more detail. This paper discusses the probable time of pockmarks formation as well as the origin of the gas.

\section{Data acquisition}

The discovery of the pockmarks in 1988 in the southem area was made by shallow seismic and echo sounder investigations. These methods have been used in five 
Fig. 1. Structural-tectonic map of the Southern Bulgarian Black Sea Zone. 1-Tectonic fractures: a) deep faults: (1) PredBalcanic; (2) -

ZadBalcanic; (3) - Rezovo; b) faults in the upper part of slope; 2 - Axes of anticlines; 3 -Surface plane of Paleogene in $\mathrm{nx} 100 \mathrm{~m} ; 4$ - Shelf/slope boundary. Area studied is shown in the lower right corner.

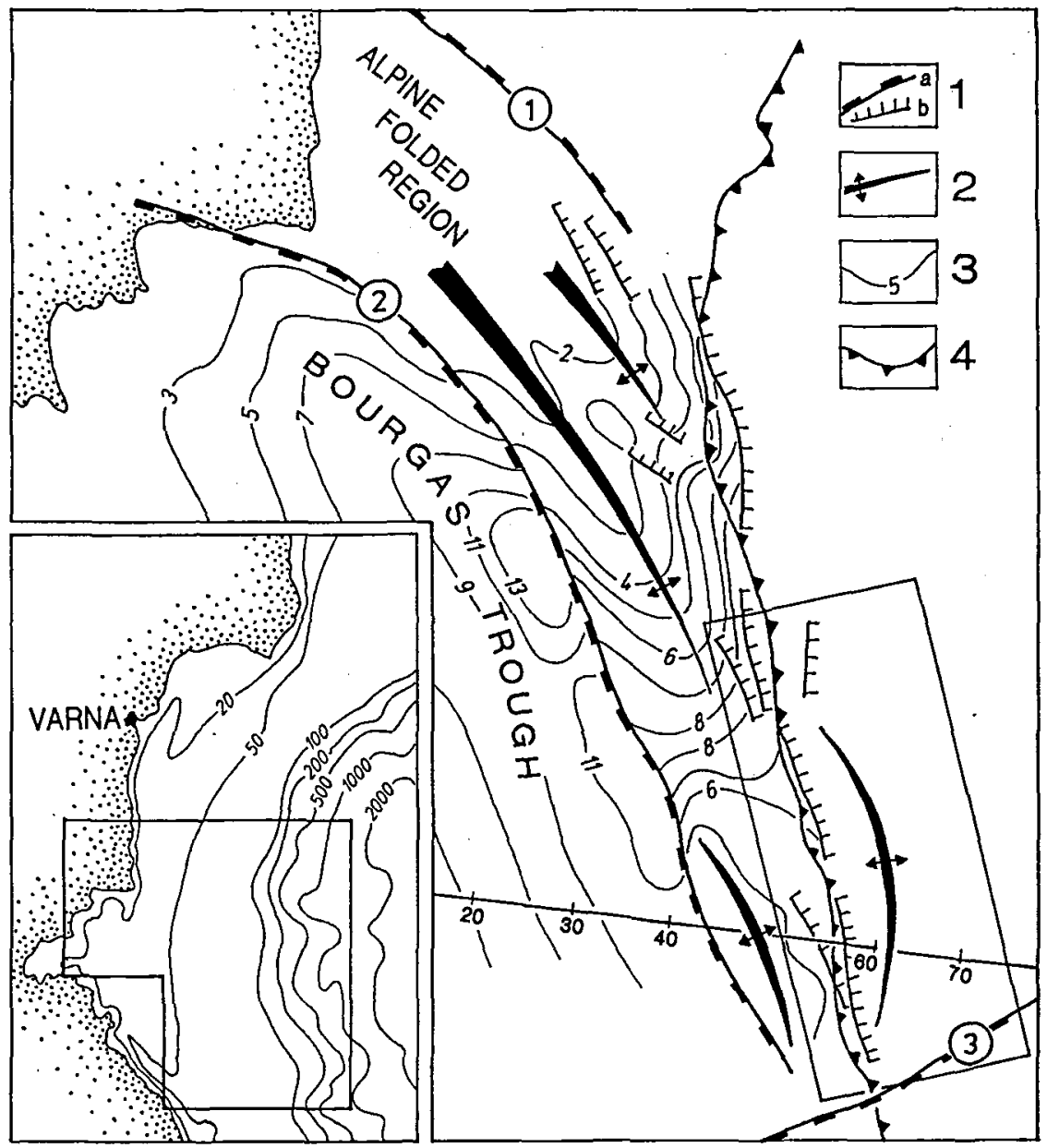

other expeditions (the authors participated in three of them) which collected data for other research projects (Dimitrov 1990). These data represent a relatively dense profile network from which a good image of the sea floor morphology and subsurface geology is gained. The sea bed deposits and some of their physical properties have been studied during separate core sampling investigations.

The shallow seismic investigations were conducted using of 3-8 electrode sparker sources with energies of 2.5 and $5 \mathrm{~kJ}$. The signal was transmitted every $2 \mathrm{sec}$ and was recorded at 1 or $2 \mathrm{sec}$ two-way travel time. The reflection signals were displayed on wet paper graphic recorder, type "INEI", and dry paper, type EPC-4800. The registration was made within the frequency range from $75-90$ to $270-340 \mathrm{~Hz}$ at central frequencies of 120-140 Hz. Exceptions are a few profiles made in 1985 which were run using a 45 electrode source with an energy of $0.8 \mathrm{~kJ}$ and a frequency range of $250-700 \mathrm{~Hz}$. The system incorporated a streamer with 5 and $7 \mathrm{~m}$ active sections. The source and the streamer were towed out of the ship's turbulent wake at a speed of 6-7 $\mathrm{kn}$ and at a water depth of $1 / 4$ wave length.

Two types of echo sounders were used: NEL-6 and SIMRAD-EA200. The NEL-6 has a very wide beam $\left(38^{\circ}\right)$ and a working range from 0 to $1000 \mathrm{~m}$, from which were received most of the data on plumes. It gives an integral image of the sea floor, but it cannot be used to localize even large pockmarks. The images of pockmarks on the low frequency shallow seismic records are similar, but more information can be gained here by careful inspection.

The thickness, lithology and physical properties (water content, porosity, density, organic carbon etc.) of the sea bed deposits were determined by our own investigations and literature studies.

Positioning of the profiles and geological samples was made by radio navigation system, type BRAS before 1990 , with a relative accuracy of $\pm 25-50 \mathrm{~m}$ in the study area. After 1990, a satellite navigation (GPS) system was used, with absolute accuracy of 0.01 nautical mile in good satellite situations and more than $100 \mathrm{~m}$ in bad ones. 


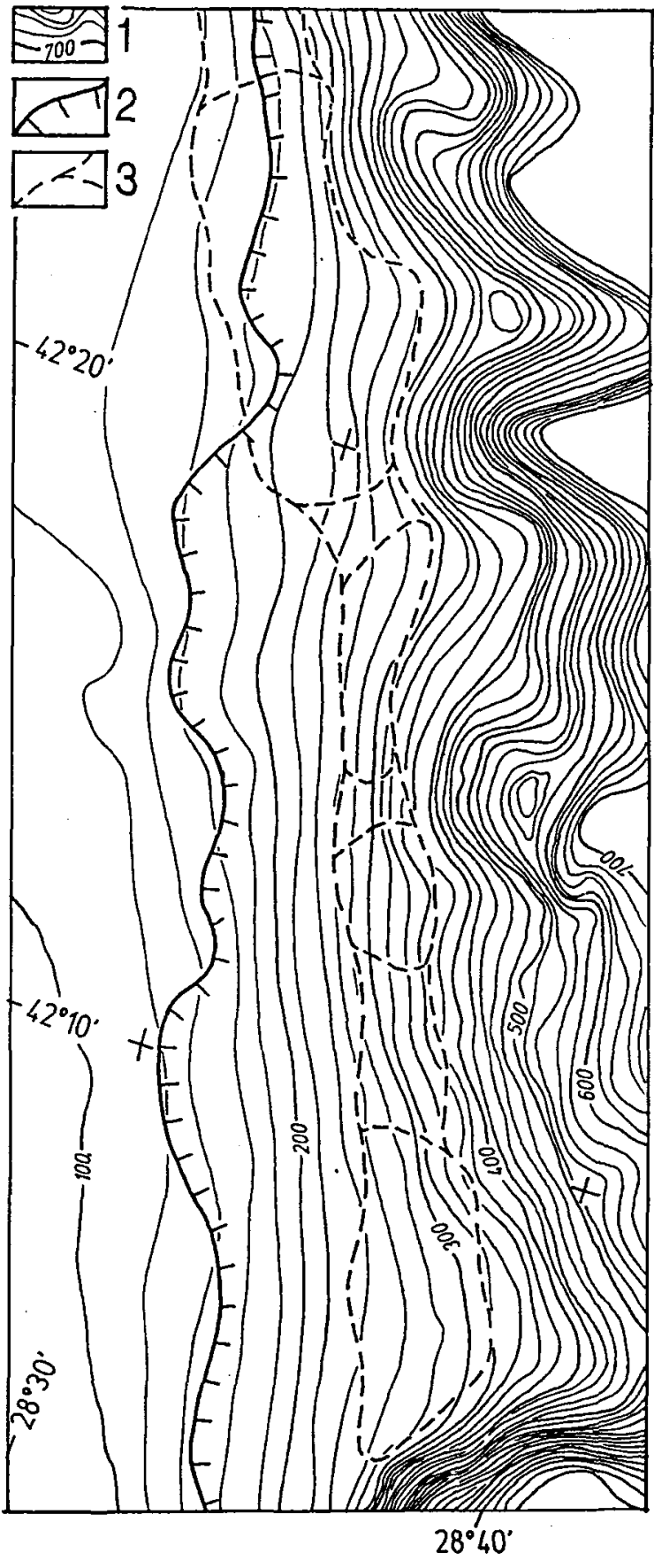

Fig. 2. Bathymetric map of the study area. 1-Water depth contours in $\mathrm{m}$; 2-Shelf/slope boundary; 3 - Contour of pockmark zone.

\section{Geological-geomorphological setting}

Fig. 1 shows the position of the study area with respect to the main tectonic and geomorphologic features of the southern Bulgarian Black Sea zone. The area is situated on the sea prolongation of the Alpine Folded Region (AFR) which is traced as anticlinal linear folds. The axes of the folds dip to the south-east and the AFR narrows because of their an echelon jointing (Kuprin 1988). Off the town of Mitchurin, where the AFR is at its narrowest, the Pliocene-Quaternary sediments lie sub-horizontally forming a saddle (Kuprin et al. 1984; Datchev 1988). The hinge of the folds rises up to the south of the saddle. Recent movements allow this part to be separated as a single morphostructure (Limonov \& Krustev 1990; Datchev 1988). The sharp boundary, ZadBalkan deep fault, separates the AFR from the Bourgas Trough to the west. The eastern boundary of the AFR is not so clear and is represented by a system of tectonic faults, active during the Quaternary (Limonov \& Krustev 1990; Kuprin 1988).

The thickness of the sediment sequence (to the upper boundary of the Cenozoic) reaches up to $12 \mathrm{~km}$, and the thickness of Quaternary sediments is more than $600 \mathrm{~m}$ at the base of the continental slope just seaward of the study area (Fig. 1). Up the slope, the thickness of sediments reduces to about $3-4 \mathrm{~km}$ (Tugolesov et al. 1985). The most likely places to discover oil and gas fields in this region are thought to be buried slopes (old slopes are considered with the recent one) from the upper Paleogene to Quaternary and the main oil source rocks are Eocene, Oligocene and Miocene sediments (Tugolesov et al. 1985; Golmshtok et al. 1989).

In relation to the geomorphology, the pockmark zone is situated in the peripheral part of the shelf and mainly in the upper part of the continental slope (Fig. 2). The end of the shelf is represented by an abrupt or a smooth flexure, but always by a visible change of the sea floor slope. The shelf/slope boundary is carried out along the forehead of the first clear flexure, although it may be met more abruptly to the seaward (Krustev et al. 1985). The slope of the shelf sea floor is about $0.5-0.7^{\circ}$ within the study area. The slope starts at relatively small angles $\left(1.2-1.5^{\circ}\right)$ but at water depths of $280-340 \mathrm{~m}$ the slope steepens from $2.5-3^{\circ}$ to $5^{\circ}$ in some places and more than $9^{\circ}$ on the northern board of the underwater valley of Rezovo (Krustev et al. 1985).

\section{Description and interpretation}

\section{Location of the pockmark zone}

The recorded 305 pockmarks are distributed irregularly within a roughly $100 \mathrm{~km}^{2}$ zone, which is subparallel to the water depth contours. The length of this zone is more than $41 \mathrm{~km}$ and the width is from 2 to $5 \mathrm{~km}$. Its northwestern part is located on the periphery of the shelf. The rest of the zone to the southeast is located on the upper part of the continental slope (Fig. 2). The pockmark zone is bounded by the northern board of Rezovo valley which coincides with the Rezovo fault (Krustev et al. 1985) from the south. The zone is unbounded to the north because of lack of data, and the presence of pockmarks is 


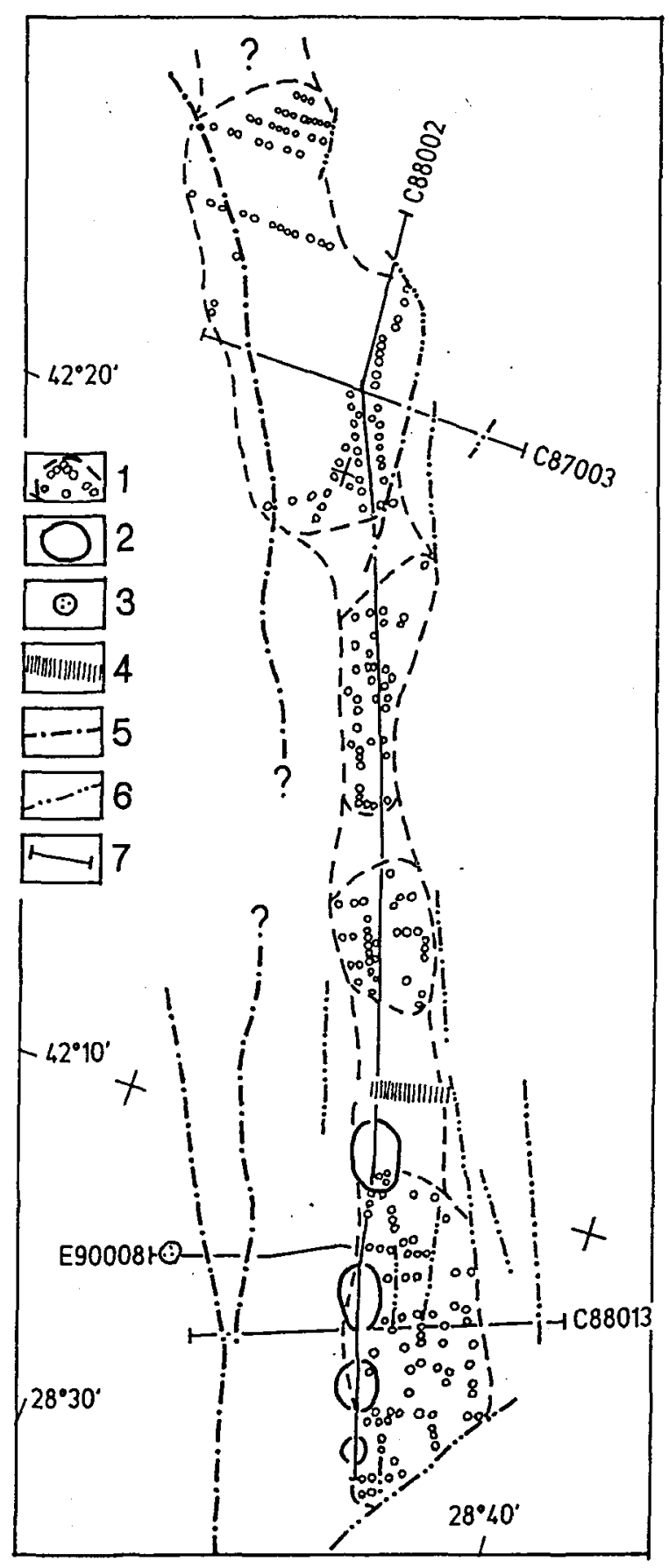

Fig. 3. Map of pockmark distribution: 1-pockmark zone; 2 "Bright spots"; 3 - "Water column" anomaly; 4 - Erosion channel; 5 - Deep faults; 6 - Consedimentation faults; 7 Shallow seismic lines.

possible there. The zone is bathymetrically limited to the west and the east and the controlling depths increase towards the south south-east from 160 to $240 \mathrm{~m}$ at the western boundary and from 230 to $350 \mathrm{~m}$ at the eastern one. The sea floor slopes vary from 1.2 to $2^{\circ}$ within the pockmark zone. Immediately to the east of the pockmark zone there is a more abrupt sea floor flexure from which a network of underwater valleys have formed. The pockmarks are grouped in two distinct regions, a southern and a northern with two smaller groups between them. It is noted that simple pockmark areas are also located on the edges of the larger underwater valleys (Fig. 2).

\section{Superfical geology}

By coring (up to $5 \mathrm{~m}$ ) only part of the Upper Quaternary sedimentary sequence has been recorded. Holocene layers are differentiated as Djemetin and ancient Black Sea layers, which are underlain by the Upper Pleistocene (Novoeuxine) sediments. The contemporary Djemetin sediments are calcareous (coccolithic) silty clay enriched in organic matter $\left(\mathrm{C}_{\mathrm{org}}: 1-3 \%\right)$. The ancient Black Sea muds consist of plastic silty clay and clayey sapropelic $\left(\mathrm{C}_{\text {org }}: 2-5 \%\right)$ sediments. There is a tendency for increasing amounts of silt in the northern part of the area. Novoeuxine deposits consist of clayey muds with a low content of organic carbon $(<1 \%)$ with spots and laminae of iron sulfide and with bubbles in some cores.

The thickness of Holocene deposits is more than $2.5 \mathrm{~m}$ in the northern part and decreases southwards before increasing again to more than $3.2 \mathrm{~m}$ in the southern part of the pockmark area. The base of Novoeuxine deposits has not been penetrated anywhere. The thickness of Holocene deposits decreases to the west (toward the shelf), and this is associated with the development of accumulative bars coinciding with an ancient coastline (Limonov \& Krustev 1990). The thickness also decreases towards the continental slope. At the base of the Holocene deposits, within the pockmarks area, a elongated depression has formed.

Measurements of some physical properties in the Holocene deposits in the upper part of the slope reveal high water contents $(150-195 \%)$ and porosity (72-84\%). In such deposits migration of interstitial solutions containing dissolved methane is difficult due to low permeability. The increasing thickness of sediment rich in organic matter also reduces the migration (Ivanov et al. 1984).

A deep fault is located just west of the pockmark zone. The fault is expressed on the sea floor and dips towards the southeast. There are also a lot of consedimentary faults within the pockmark area which also slump seaward on the slope (Fig. 3).

\section{Pockmark size and distribution}

Pockmarks depth, diameter, shape and linear density were directly determined from the SIMRAD echosounder and high frequency shallow seismic records. From these data the slope of the pockmark walls was calculated and the density per square $\mathrm{km}$ was estimated. Their shape in plan view is not known because only a few pockmarks 

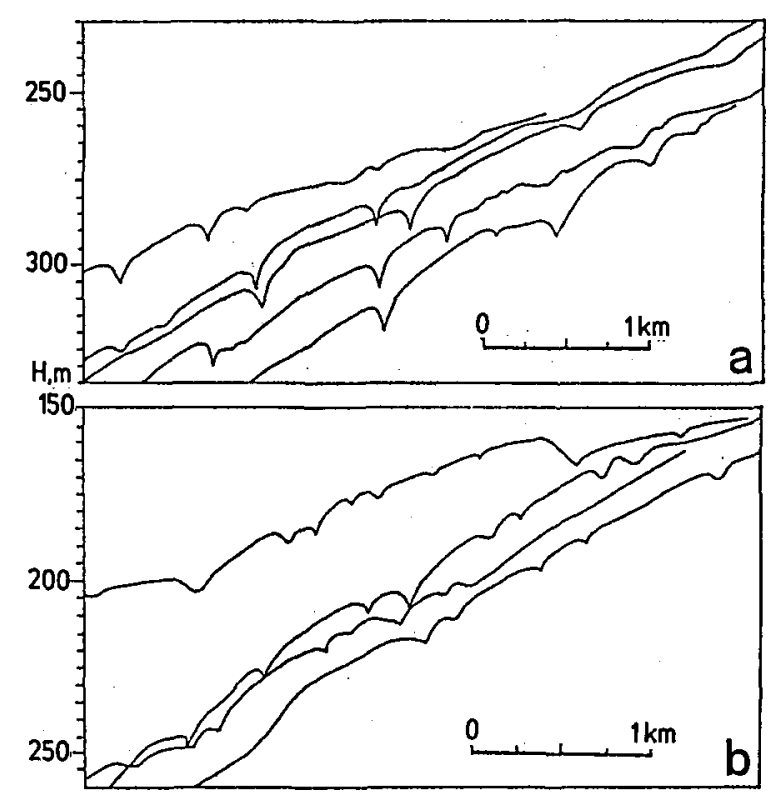

Fig. 4. Characteristic echo-sounder profiles from the southern (a) and the northern (b) pockmark areas. The difference between them is clearly seen.

were crossed in more than one direction, there is a relatively high error in specifying their diameter (about 10\%) and the locality of an individual pockmark cannot be guaranteed on two or more records. On the other hand, the profile line may cross a pockmark over its centre, i.e. over its deepest point, although the chances are very small. This is why we call the measured parameters for visible parameters.

The visible pockmark depths vary from less than $1.5 \mathrm{~m}$ to more than $7 \mathrm{~m}$, their visible diameter - from $50 \mathrm{~m}$ to more than $200 \mathrm{~m}$; no relationship between these two parameters has been established. The shape of their profile varies from a smooth U-shape to a sharp V-shape. There is tendency for shallow large $U$-shaped depressions to be situated in shallow water depths. Towards deeper water their depth increases and their shape changes to a V-shape in the southern area (fig. 4). Such a tendency is not established in other areas where both pockmark types are located irregularly. The slope of walls in the Ushaped pockmarks varies from 2 to $5^{\circ}$ (average $3^{\circ}$ ) and that of the V-shaped pockmarks from $3^{\circ}$ to more than $10^{\circ}$ (average $6^{\circ}$ ) and usually the lower walls have a steeper slope.

Fig. 5 shows histograms of pockmark depths and diameters for the southern and northern areas. They are based on 31 measurements from the southern area and 34 from northern area, though this has been reduced to 31 for a better comparison. It is clearly seen that the pockmarks within the northern area have a relatively small size, with an average visible depth of $1.75 \mathrm{~m}$ and an average visible diameter of $86 \mathrm{~m}$. The pockmarks within the southern area are consistently larger, with an average visible depth of $4.1 \mathrm{~m}$ and an average visible diameter of $132 \mathrm{~m}$.

The estimated pockmark density within the northern area is approximátely 7-9 p.m. per $\mathrm{km}^{2}$ but only about half this density within the southern area (3-4 p.m. per $\mathrm{km}^{2}$ ). The sizes of pockmarks within other areas are close to those from the northern area and their density has medium values of 4-6 p.m. per $\mathrm{km}^{2}$. The data suggest that pockmark density is inversely proportional to their size, i.e. the smaller the pockmarks, the higher is their density.

We think that it is important to note the orientation of the vertical pockmark axes. There are two orientations of this axis - perpendicular to the water surface or to the sea floor. It is noticed that the axes of the large V-shaped pockmarks from the southern area have a preferred orien-
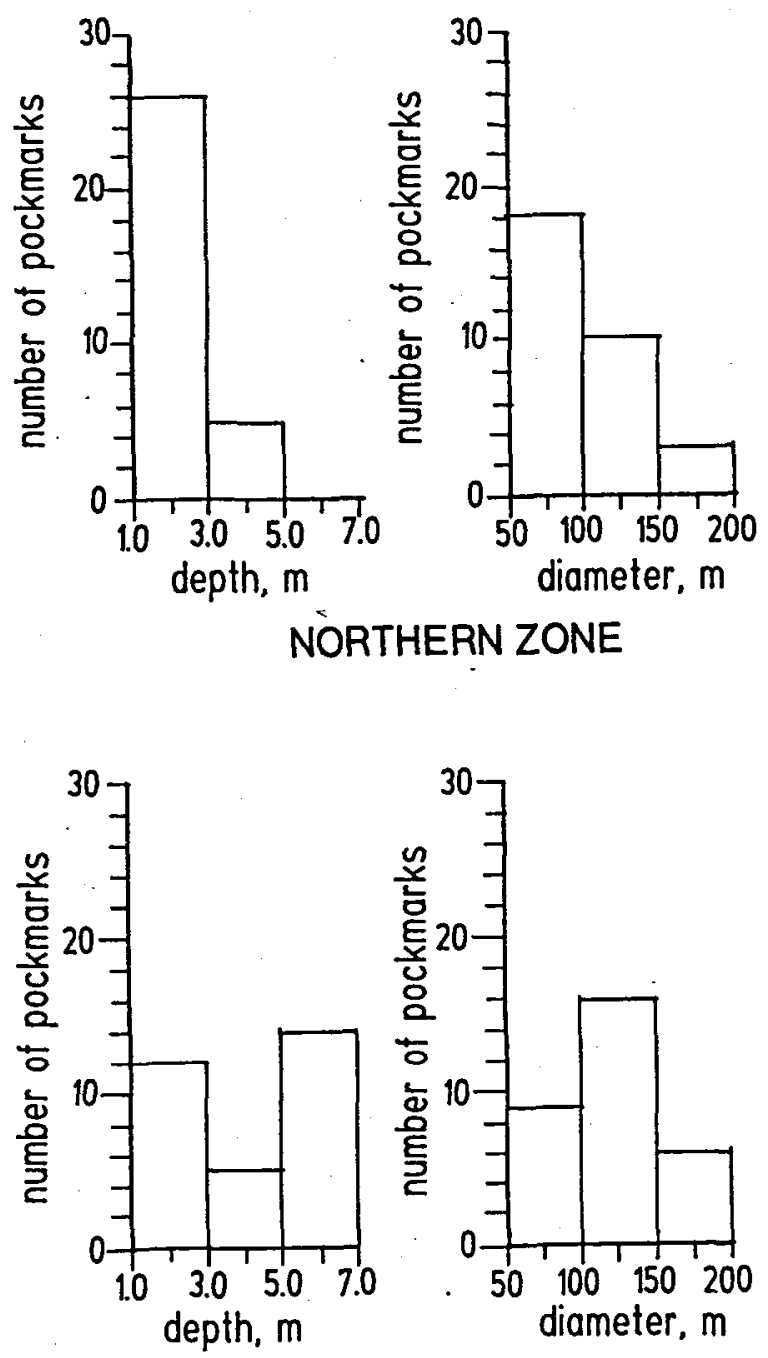

SOUTHERN ZONE

Fig. 5. Histograms of pockmark distribution in visible depths and diameters of the northern and southern areas. 

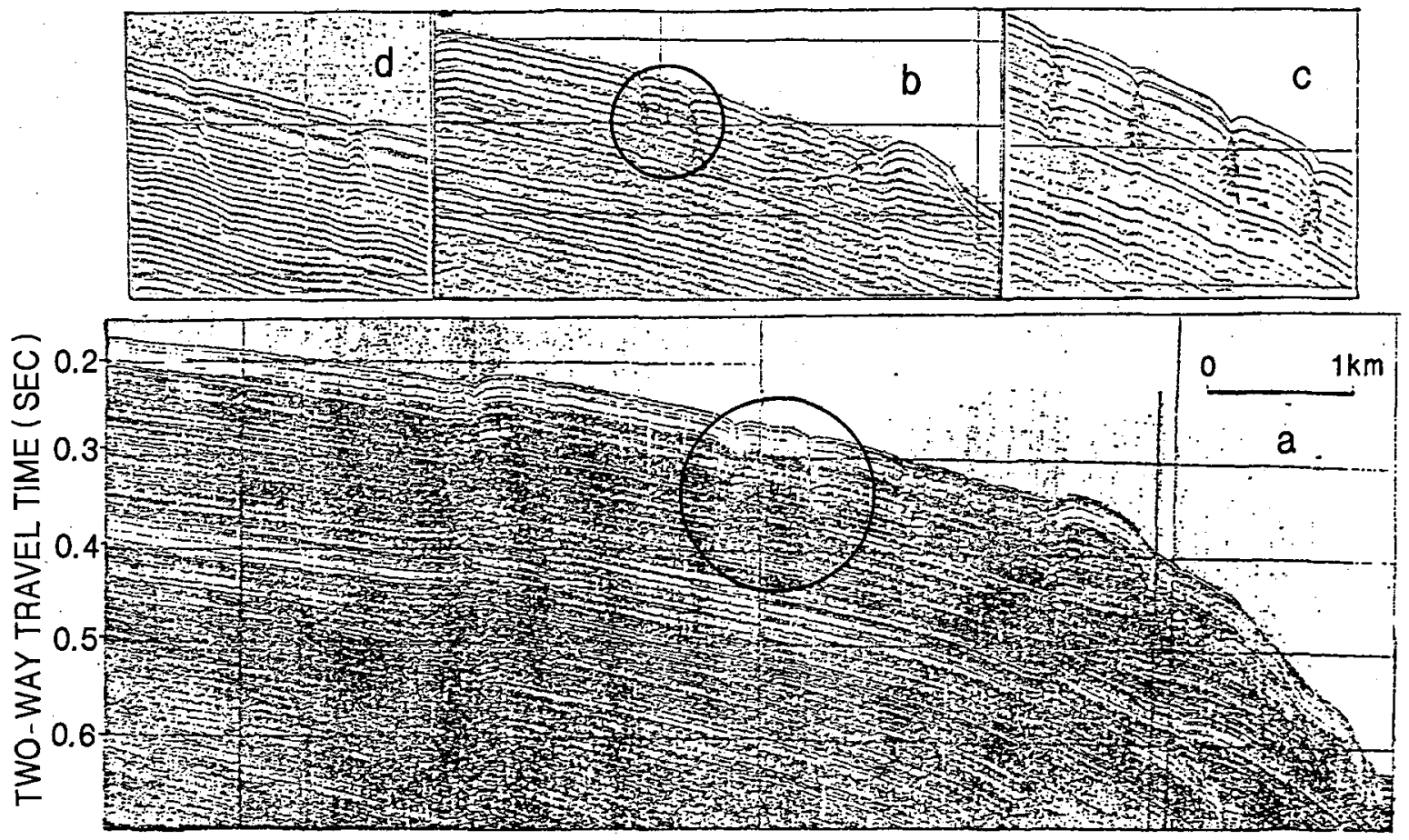

Fig. 6. Sparker profiles showing different images of gas pockets below the pockmarks. a) high frequency section (line C87003 on Fig. 2) on which the gas pockets and the channels of turbid sediments can be clearly seen; b) the same section recorded in frequency range $120-340 \mathrm{~Hz}$ on which the gas pockets have a different image; $\mathrm{c}$ and d) sections from other locations in the pockmarks area.

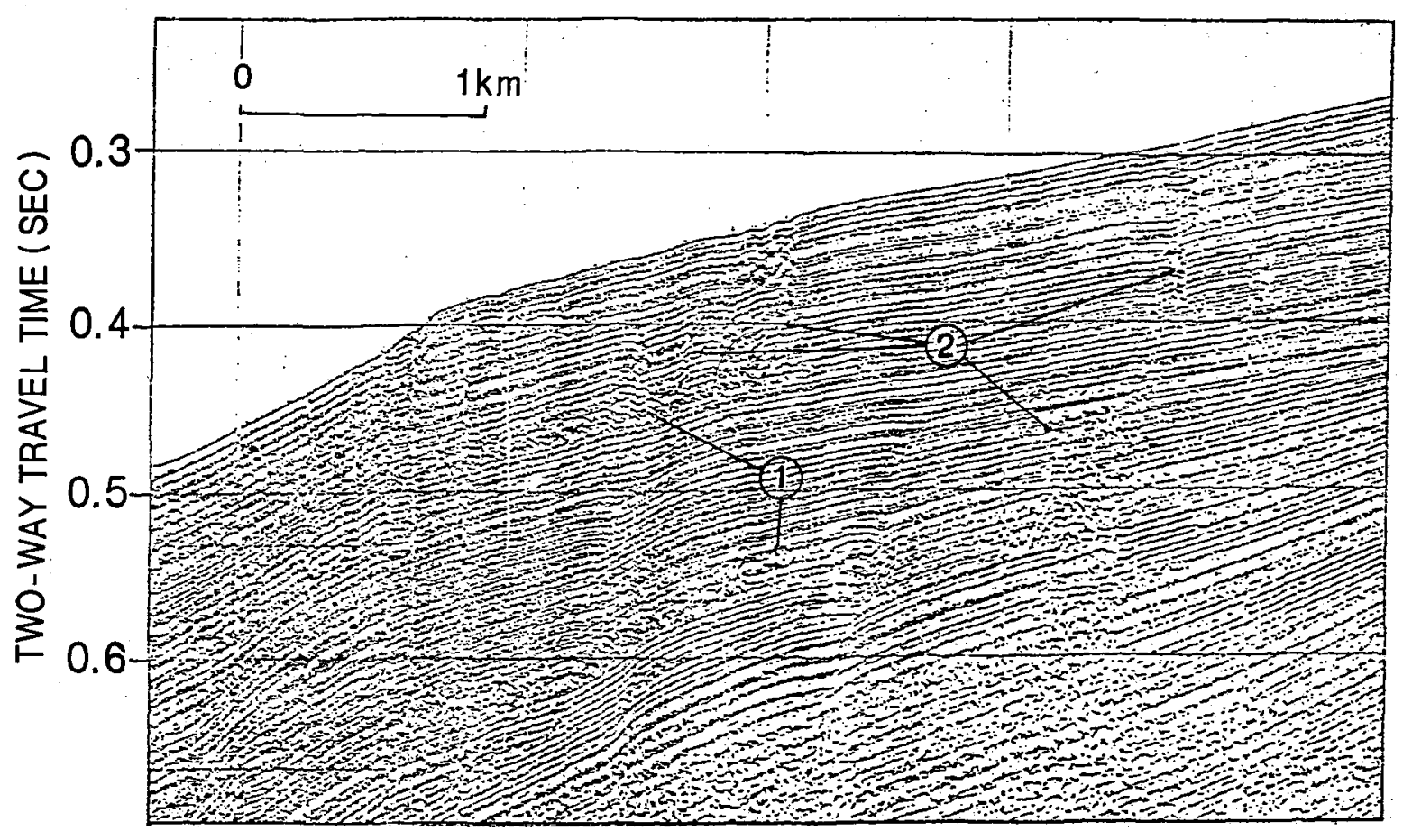

Fig. 7. Sparker section (line C88013 on fig. 3) showing gas-charged layers (1) and gas migration paths (2).

Dimitrov \& Doncheva: Seabed pockmarks 


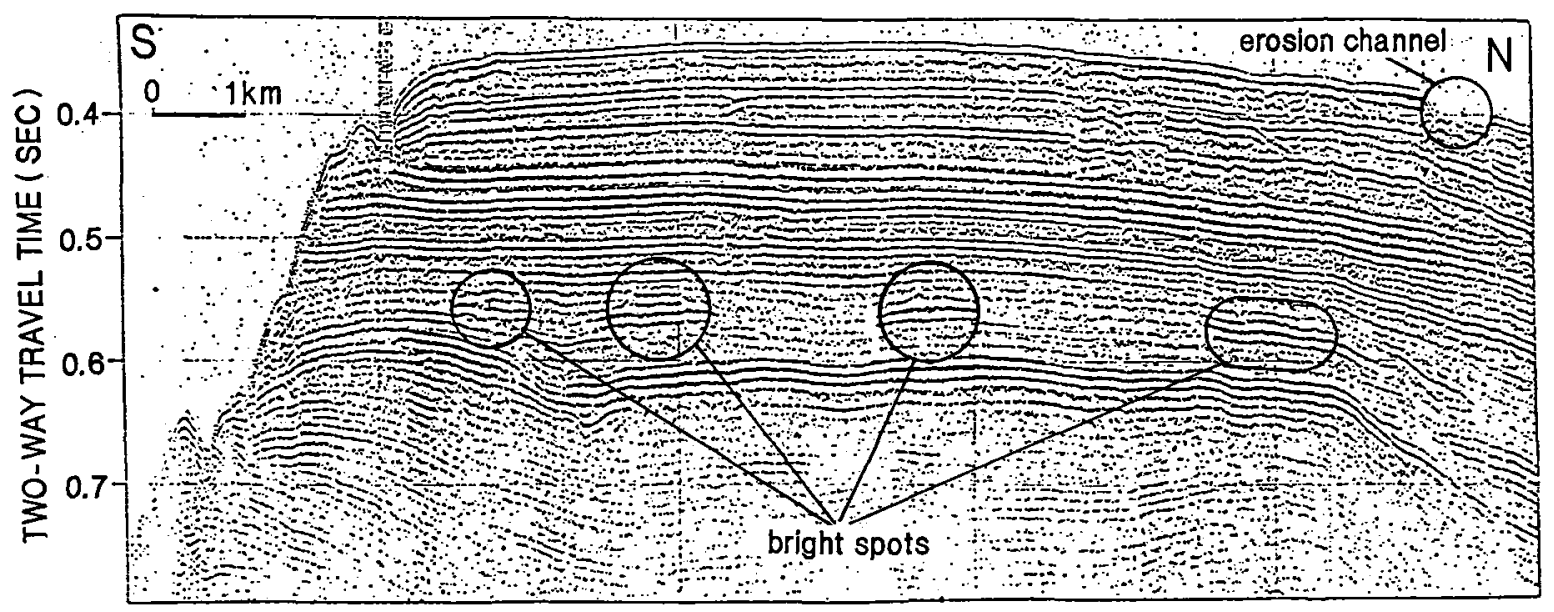

Fig. 8. Sparker profile from the southern pockmark area (line C88002SN on fig. 3) showing the anomaly type "bright spots". The high reflection amplitudes and the polarity inversions are clearly seen.

tation of the axis which is perpendicular to the water surface, whereas within other areas such a relation is not observed.

The sub bottom seismic configuration of buried pockmarks has been localized on a few profiles. The features are situated at a two way travel time of $60 \mathrm{msec}$ below the sea bed, just west from the central part of the pockmark zone. The data are insufficient to allow mapping of the buried pockmarks.

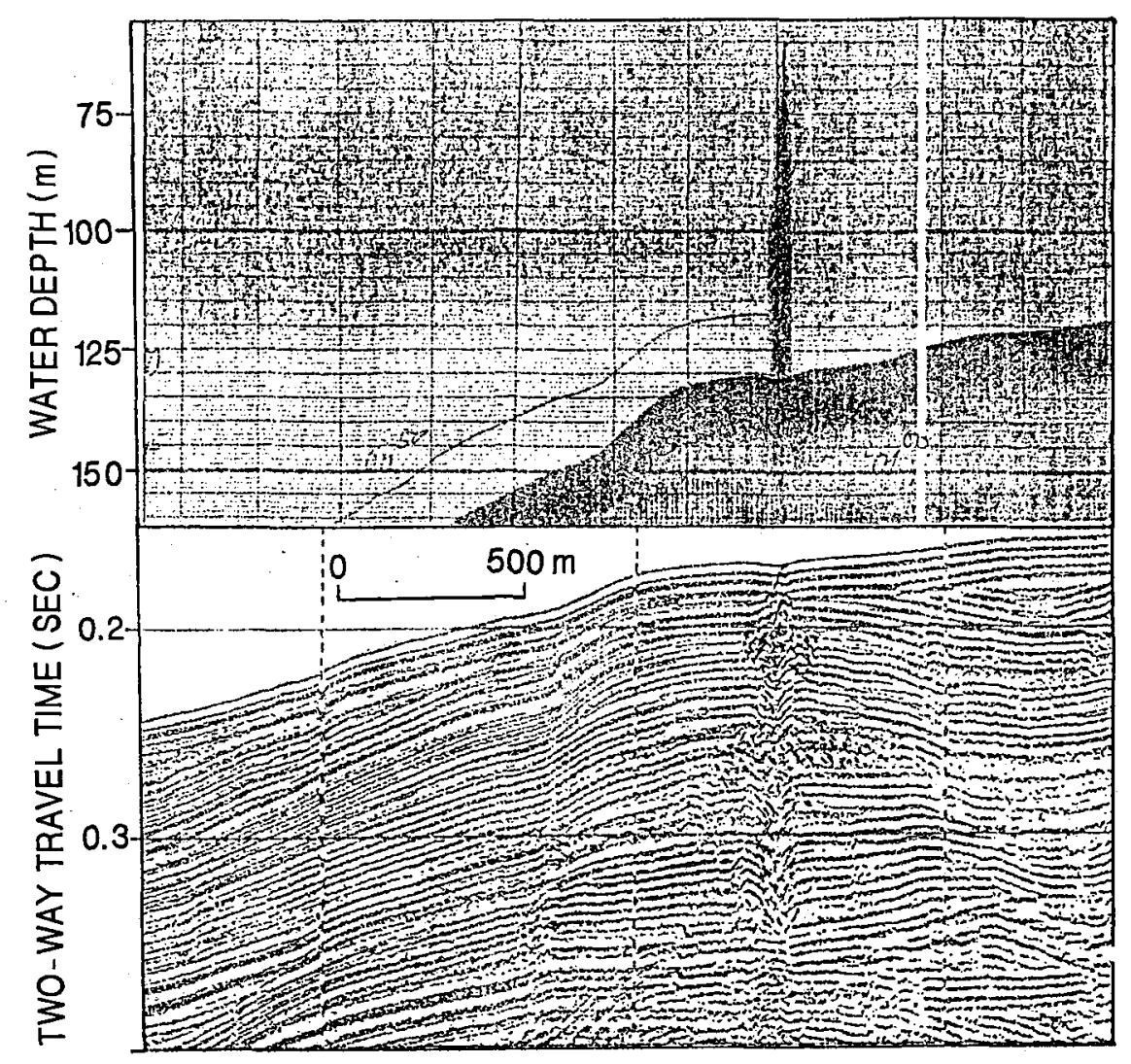

Fig. 9. Echo-sounder profile and its corresponding sparker profile (line E90008 on fig. 3) showing a water column anomaly and acoustic turbidity in the sediments below it. 


\section{Gas-acoustic anomalies}

In many places within the study area, numerous acoustic anomalies thought to indicate the presence of gas in sediments have been recorded.

Most of the pockmarks on low frequency records are accompanied by a sub bottom acoustic anomaly which is rather long and steep to be only due to diffracted waves or the "bow-tie" effects (Figs 6 and 8). A comparison between two sections of the same profile recorded with different registration parameters shows this. Acoustic voids are clearly seen below pockmarks on the high frequency $(270-760 \mathrm{~Hz}$ ) section (Fig. 6a) and a pulldown effect is seen at their edges due to the increase of the elastic wave velocity. These voids are connected with the pockmark depression by acoustically turbid channels. The anomalies on low frequency sections (Fig. 6b, c, and d), expressed like those described above, are interpreted as a generalized image of gas-pockets and possible gas migration paths.

Acoustically turbid and blanking layers which are characterized by numerous short, chaotic seismic reflections or lack of coherent ones, are often recorded just below the sea bed reflection and also in deeper sections. The most characteristic layers with such a seismic configuration are localized in the upper part of the slope. The top of the first layer is normally at $80-85 \mathrm{msec}$ two-way travel time below the sea bed and usually has a diffracted seismic configuration (Fig. 7). The refractions may be caused by surface roughness, probably caused by an irregular gas diffusion front in the covering deposits. The seismic configuration often has acoustically turbid channels which extend to the sea floor in the pockmark zone. The top of the second layer is at about $200 \mathrm{msec}$ with a time thickness of $30-35 \mathrm{msec}$ and is similar to the first layer just west of the pockmark zone (Fig. 7). There are four "classic" bright spots within the second layer. They are situated at the western boundary of the southern pockmark area (Fig. 3). In addition to high reflections amplitude there are polarity inversions, increase of the visible frequency from about $150 \mathrm{~Hz}$ to $120 \mathrm{~Hz}$, and weakening of the intensity of the relatively strong reflection below the bright spots (Fig. 8). All these data suggest that gas-charged sediments and gas migration within the upper sediment sequence are widespread features.

The release of free gas from the sea bed has been recorded both within the pockmark zone and in the neighborhood (acoustic plumes in the water column). The most "visible" anomaly is situated just offshore of the shelf/ slope boundary (Fig. 3) in a water depth of $131 \mathrm{~m}$. This is a strong plume on the echo sounder record (Fig. 9a) and the sediments are acoustically turbid along their vertical axis on the corresponding seismic section (Fig. 9b). Moving upwards through the sediments to the sea bed the gas evidently saturates and charges some (permeable) layers around the axis where the conditions allow it, forming specific "turbid" lateral structures. It must be noted that in the plane of the plume there is a shallow large depression on the sea floor.

\section{Discussion}

\section{Pockmark age and formation}

It may be concluded from these data that at least some of the Quaternary sediments are gas-charged. In some places there are indirect indications for diffusion and gas flow within and through the sediments up to the sea water. The pockmarks occur in places where the gas is intensively venting, seeping, or erupting.

If the pockmarks had been formed by continuous gas seepage which did not allow sediment deposition, the deepest pockmarks would have formed during the last 15-19,000 years, with a Holocene deposition speed of 0.4-0.5 m per 1000 years (Sorokin \& Dimitrov 1980). During that time there were also a different thermobarometric condition in the study area, causing the sea level to be $90-100 \mathrm{~m}$ lower than today (Fedorov 1988). This could have initiated pockmark formation. On the other hand, the relatively high deposition rate combined with slumping and plastic flow (Chochov \& Shanov 1987) suggests that pockmarks are much younger and probably formed during the Holocene. Furthermore, the water column anomalies above some pockmarks suggests that their activity continues to the present day.

The V-shaped pockmark wall slope is critical for stability of the bottom deposits. Probably they contain material slumped from the sides into the central depressions, which would account for the profile shape changing from a V-to a U-shape. The co-existence of U-shaped shallow pockmarks and of V-shaped deep pockmarks on the sea bed is probably due to some being inactive (U-shaped) and some being new or active (V-shaped).

The presence of gas-charged layers at different depths, connected with columns of acoustic turbidity, suggests that there probably exists a process of gas transmission and accumulation in shallow, temporary reservoirs. The Holocene deposits covering these reservoirs have ideal sealing properties, which are strengthened by the presence of plastic sapropelic muds included in them. In our opinion, if the pockmarks are formed after the deposition of these sediments, only "explosions" or sudden eruptions will be able to penetrate this cover.

The main triggering mechanism for the gas eruptions would be suddenly changing thermo-barometric conditions within the shallow reservoirs. The cause of such changes could be earthquakes, faulting, slope slumping, "internal fluid pressure waves" (Hovland \& Judd 1988) or human activity. The specific location (in the upper part of the slope in water depths more than $160 \mathrm{~m}$ ) and shape (elongated with length more than $41 \mathrm{~km}$ ) of the pockmark area excludes the latter reason. Due to widespread faulting and slumping within the area, as well as the proximity to earthquake zones (the centre of the study area is lo- 


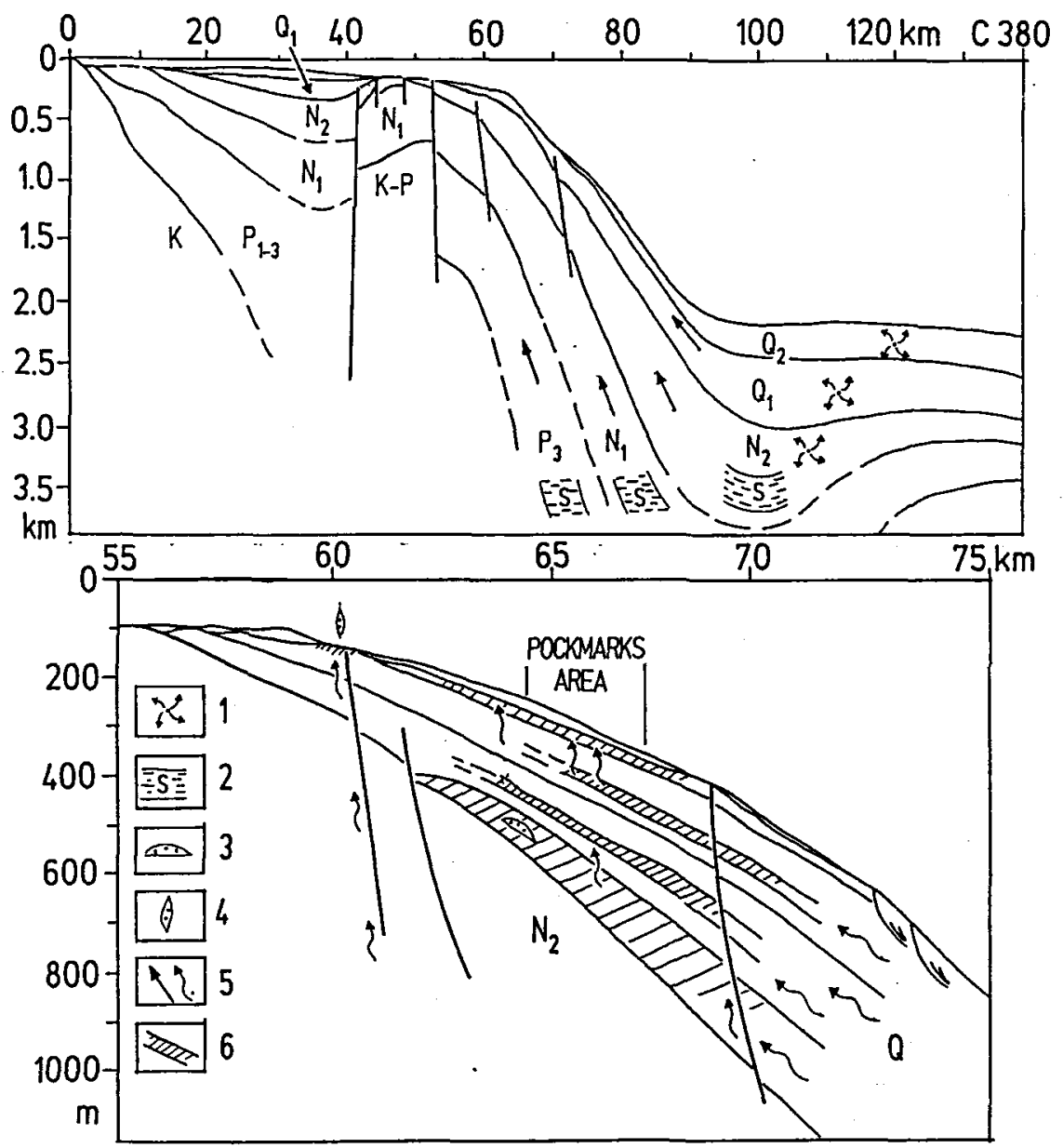

Fig. 10. Generalized section across the study area and site 380 from DSDP: 1-Biogenic gas generation sediments; 2 Oil source rocks; 3 - Gas fields in the Quaternary sediments ("bright spots"); 4 Gas plume in water column; 5 - Direction and paths of gas migration; 6 - Gas-charged sediments.

cated at a distance of $120 \mathrm{~km}$ from the Shabla earthquake zone and about $160 \mathrm{~km}$ from the Anadola zone) it appears that natural triggers are most likely cause for the release of gas and formation of pockmarks.

\section{Genesis of the gas}

We have no analyses of gas composition and origin, though there have been a few results from the methane in the Quaternary sediments. The samples were made just offshore of the pockmark zone, in the peripheral part of the shelf and to the east, at the slope base. The data suggest that the methane here is of a biogenic type, with a $\delta^{13} \mathrm{C}$ value ranging from $-78.4 \%$ to $-81.8 \%$ PDB (Ivanov et al. 1984). DSDP hole 380/381 analyses show that the hydrocarbon gases within the Quaternary sediment sequence are biogenic and were formed in situ (Hunt \& Whelen 1978).

If the gas which is responsible for the pockmarks is formed within the Quaternary sediments, it may be concluded that it is biogenic. In that case the gas may be formed in situ in the local sediments and/or it may have migrated up from the slope base where the thickness of the Quaternary sediments is greatest to the upper parts of the slope (Fig. 10). This may also be confirmed by shallow seismic sections on which the gas can be traced out as a gas-charged layer along all stretches of the slope.

On the other hand, the presence of numerous active faults within and around the pockmark zone makes it very probable to suggests that there is a migration of thermogenic gas along them.

\section{Conclusions}

The main conclusions of this study are:

1. Sea bed pockmarks and subsurface features that indicate the presence and passage of gas in and through the sediments to the water column are widespread along a narrow zone in the southern Bulgarian Black Sea zone. The main agent for pockmark formation appear to be actively venting gas. The most probable mechanisms, responsible for the release of the gas, appear to be earthquakes, active faulting, slope processes and possibly "internal gas pressure waves".

Bulletin of the Geological Society of Denmark 
2. The gas appears to have a mixed origin and includes biogenic gas which is formed in situ and/or has migrated from the slope base to the upper parts as well as thermogenic gas which has migrated along faults.

3. The water depths, the thickness and granulometric composition of the sea bed sediments have been found to influence the pockmark size and distribution.

4. The most probable time period for pockmark formation appears to be just before and during the Holocene time. Presentday on-going pockmark activity is also very possible.

For the future it is important to make a side-scan sonar mosaic of the sea floor of the pockmark zone, to determine the gas composition and to attempt to quantify the amount of gas released by venting processes from the sea bed through the sea water to the atmosphere.

\section{Dansk sammendrag}

I 1988 blev der for første gang observeret pockmarks i det sydøstlige omrăde af den bulgarske del af Sorte Havet. 305 pockmarks er indtil dato blevet registreret indenfor et areal på ca. $100 \mathrm{~km}^{2} \mathrm{i}$ en langstrakt zone på $2-5 \mathrm{~km}$ i bredden og $41 \mathrm{~km}$ i længden. En detaljeret kortlægning ved hjælp af ekkolod og seismiske undersøgelser tyder på en karakteristisk geografisk fordeling af pockmarks efter størrelse, dybde og form fra den nordlige til den sydlige del af området. Fordelingen af form og størrelse synes at være betinget af vekslende vanddybde, mægtighed og kornstørrelsessammensætningen af de overfladenære marine sedimenter.

De seismiske profiler i området er karakteriseret af hyppige akustiske anomalier, der tolkes som tilstedeværelse af betydelige mængder af gas i sedimenterne. Der er ligeledes observeret gasudstrømning direkte i vandsøjlen, specielt $\mathrm{i}$ områder med pockmarks. Dannelsen af pockmarks formodes derfor at være forårsaget af aktiv gasudstrøming i havbunden. De geologiske forhold tyder på, at dannelsen af pockmarks har fundet sted i Holocæn tid og at den formentligt også løbende finder sted i dag. Gassen formodes at være dannet som biogen gas in situ i de kvartære sedimenter, men der kan også være tale om en thermogen oprindelse, og at gassen via forkastningssystemer når frem til overfladen fra dybere liggende reservoirer.

\section{References}

Berard, B. B., Brooks, J. M. \& Sacket W. M. 1976: Natural gas seepage in the Gulf of Mexico. Earth Planet. Science Lett. 33, 48-54.

Blazchishin, A. \& Lange, D. 1984: Geologo-geofisicheskie issledovania v Baltiiskom More. Okeanologiya 29(5), 855-860.
Chochov, S. D. \& Shanov, S. B. 1987: Holocene breccia from bottom sediments in the western half of the Black Sea. Bulgarian Academy of Sciences Bull. 40(2), 71-74.

Datchev, H, 1988: Structure of the earth crust in Bulgaria. "Technika" Publ., Sofia, 356 pp.

Dimitrov, L. I. 1990: Form tipa kraterov na dne Chernogo more. Bulgarian Academy of Sciences Bull. 43(5), 37-39.

Fedorov, P. V. 1988: Problema izuchenija Chernogo morja v Pleistocene Bull. MOIP, 63(4), 55-61.

Golmshtok, A., Trocjok, V. \& Hahalev, E. 1989: In: Problems of Petroleum Content in the World Ocean. "Nauka" publ., Moscow, 146-169.

Hovland, M. 1981: Characteristics of pockmarks in the Norwegian Trench. Marine Geology 39, 103-117.

Hovland, M. 1983: Pockmarks and recent geology of the central section of the Norwegian Trench. Marine Geology 47(4), 283-301.

Hovland, M. 1984: Gas-induced erosion features in the North Sea. Earth Surface Processes and Landforms 9, 209-228.

Hovland, M. 1987: The formation of pockmarks and their potential influence on offshore construction. Proc. of JSCE 388/ III-8 (Geotechnical Eng.), 13-22.

Hovland, M. \& Judd, A. 1988: Seabed pockmarks and seepages. Graham and Trotman Inc., Sterling House, London, 293 pp.

Hunt, J. M. \& Whelen, J. K. 1978: In: Initial Report of DSDP, XLII, part 2, 661-678.

IvanoIvanov, M., Vainshtein, M., Galchenko, V. et al. 1984: In: Oil and Gas - genetic studies of the Bulgarian sector of the Black Sea, Bul. Academie of Sciences Publ., Sofia, pp. 150 180.

Jansen, J. 1976: Late Pleistocene and Holocene history of the North Sea, based on the acoustic reflection records. Netherland J. of Sea Sciences 10, 1-43.

Josenhans, H. J., King, L. H. \& Fader, G. B. J. 1978: A side scan sonar mosaic of pockmarks on the Scotian Shelf. Canadian Journal of Earth Sciences 15(5), 831-840.

King, L. H. \& MacLean, B. 1970: Pockmarks on the Scotian Shelf. Geol. Soc. Am. Bull. 81, 3141-3148.

Krustev, T., Volokitina, L., Parlichev, D. et al. 1984: In: Oil and Gas - genetic studies of the Bulgarian sector of the Black Sea, Bul. Academie of Sciences Publ., Sofia, pp. 46-57.

Krustev, T., Dachev, H., Limonov, A. et al., 1985: Morphostructural features of continental slope in the western part of the Black Sea. Geol. Balc. 14(3), 65-80.

Kuprin, P. N., Kalinin, A. V., Krustev, T. I. \& Morgunov, U. V. 1980: In: Geological and geophysical researches in the Bulgarian Black Sea Zone. Bull. Academie of Sciences Publ., Sofia, pp. 166-178.

Kuprin, P. N. (editor) 1988: Istoria geologicheskogo razvitia kontinentalnoi okrainine zapadnoi chasti Chernogo morja., MGU Publ., Moskow, 312 pp.

Limonov, A. \& Krustev, T. 1990: In: Geological evolution of the Western Part of the Black Sea Basin during Neogene Quaternary. Bul. Academie of Sciences Publ. Sofia, pp. 305331.

Nelson, H., Thor, D., Sandstrom, M. \& Kvenvolden, K. 1979: Modern biogenic gas generated craters (sea-floor pockmarks) on the Bering Shelf Alaska. Geol. Soc. Am. Bull. 90, 11441152.

Sorokin, V. M. \& Dimitrov, P. S. 1980: In: Geological and geophysical researches in the Bulgarian Black Sea Zone. Bul. Academie of Sciences Publ., Sofia, pp. 238-245.

Tugolesov, D. A., Gorshkov, A. S., Maisner, L. B. et al., 1985: Tectonica Mezocainozoiskih otlogenii Chernomorskoi Vpadine. "Nedra" Publ., Moskow, 215 pp.

Werner, F. 1978: Depressions in mud sediments (Eckenfoerde Bay, Baltic Sea) related to sub-bottom and currents. Meynana 30, 99-104. 